\title{
ORGANIZAÇÃO DA LINGUAGEM E ORDEM DESEJANTE EM ESAÚ E JACÓ DE MACHADO DE ASSIS
}

\section{Lincoln Braga Villas Boas*}

Resumo: Este artigo tem por objetivo analisar os elementos que constituem, na narração de Esaú e Jacó, de Machado de Assis, uma ordem outra que aponta para o percurso da encenação do desejo, determinante das escolhas e dos destinos das personagens. Tomam-se por base as posições das personagens Natividade e Conselheiro Aires e a organização da linguagem usada pelo autor do romance.

Palavras-chave: crítica psicanalítica; narração; desejo

A importância da obra literária de Joaquim Maria Machado de Assis (1839 - 1908) é indiscutível no cenário da literatura nacional e permanece ainda hoje uma fonte inesgotável de estudos. Este autor, que incursionou por todos os gêneros literários conhecidos, pode muito bem ser um dos alvos da afirmação de Harold Bloom (1995) acerca de uma originalidade literária forte que se torna canônica, o que o coloca como um modelo de excelência estética, definidora de sua voz autoral inconfundível.

A multiplicidade de leituras e recepções que essa voz autoral invoca torna, em especial, o aspecto narrativo ${ }^{1}$ de seus contos, novelas e romances o objeto de diferentes interpretações, quer se tomando por base os motivos estilísticos, os temáticos e os estruturais - enfocados pela Teoria Literária -, quer os sociais, políticos e culturais consagrados pela critica literária em suas mais variadas acepções e abordagens. Ao que se pode aditar a atualidade viva de sua produção que ultrapassa a aparência meramente datada que a remete a um tempo cronológico onde se deu.

* Psicólogo e psicanalista. Aluno do Programa de Pós-graduação em Letras e Linguística do Centro de Ciências Humanas Letras e Artes, Ufal.

1 Consideramos aqui aspecto narrativo o delineamento do modo de narrar em sua feição exterior, ou seja, a aparência da narração. 
Essa produção, que data da segunda metade do século XIX e segue até a primeira década do século XX, arremete-se a um aporte da condição humana universal, enfocando-a através de ângulos diversos, revelando-se a agudeza psicológica de um observador sagaz e cauteloso. E é esta agudeza psicológica que coloca o aspecto narrativo desta produção como objeto da interpretação psicanalítica.

Os recursos estilísticos dos quais o autor lança mão perfazem operações discursivas correlatas das formações do inconsciente, como bem assinala Roberto Schwarz (1990), que levanta essa possibilidade interpretativa, a psicanalítica, declarando que o modo machadiano de narrar assemelha-se à maneira do que Sigmund Freud indicaria a propósito da elaboração onírica, a saber, do trabalho do sonho. Porque há no aspecto narrativo machadiano, fartamente encontráveis, desvios das normas gerais da linguagem que permitem a criação de novos sentidos e novos nexos que tomam por base a analogia, a substituição, a omissão, a oposição e outros operadores.

Assim sendo, pelo que se articula no aspecto narrativo e no que nele produz o manejo da linguagem, pode-se trilhar em sua constituição as operações análogas às formações do inconsciente e indicativas de uma encenação ou realização do desejo $^{2}$ das personagens, desejo este que determinaria suas escolhas e seus destinos. As operações discursivas permitem entrever uma ordem desejante, ou seja, um arranjo que se subordina ao principio de satisfação do desejo para representá-lo estética e imaginariamente como realizado. São decerto os desvios das normas gerais da linguagem que operam, discursivamente, $\mathrm{o}$ aspecto narrativo $\mathrm{e}$ instauram nele uma outra ordem.

Essa característica que se pode identificar mais notadamente nos romances da maturidade de Machado de Assis se reforça a partir de Memórias póstumas de Brás Cubas (1880/1), reverbera em Esaú e Jacó (1904) - aqui revelando-se sua urdidura mais acabada - e desemboca em Memorial de Aires (1908), sob a égide da astúcia mais refinada que atinge seu ponto máximo de realização literária.

2 Formação psíquica em que o desejo é imaginariamente apresentado como realizado. As produções do inconsciente são realizações do desejo em que este se exprime de uma forma mais ou menos disfarçada. 
Pode-se supor, desde uma premissa da crítica estética, que, se um escritor escreve principalmente para se livrar da influência dos outros (BLOOM, 1995), Machado de Assis levou ao fim e ao cabo essa intenção ordenadora da escrita, firmando não somente sua voz autoral como sua posição no cenário da literatura nacional como um dos maiores, senão o maior escritor brasileiro.

Uma outra ordem que pode ser trilhada no aspecto narrativo machadiano, a ordem desejante, demarcada pelos desvios da linguagem, cujo arranjo se subordina ao princípio da satisfação do desejo, é a via que tomamos como base para nossa análise. E visamos, em particular, o romance Esaú e Jacó.

A crítica literária contemporânea tem identificado em Machado de Assis, para além de uma cosmovisão assentada num lapidar ceticismo, seu manejo da linguagem para retratar certas emoções humanas que só teriam lugar a partir de motivações inconscientes. Torna-se procedente, então, a afirmativa de Jacques Lacan (1966) de que o inconsciente se estrutura como uma linguagem, como um discurso cuja ordem institui o ocultamento dos efeitos de sentido que se esquivam não só à escuta, esquivam-se também à leitura e essa afirmativa já é uma derivação do que Sigmund Freud ([1900]1973) considerava em sua interpretação do sonho e reverte para uma abordagem psicanalítica pioneira e original da obra de Wilhelm Jensen O delírio e os sonhos em "A Gradiva" de W. Jensen ([1907]1973).

Schüler (1989) destaca essa esquivança do lado do narrador em seu manejo do artificio que deixa ao leitor sempre algo a compreender, referindo-se ao que, no aspecto narrativo, escapa à compreensão. É algo que, como por sua vez refere Serge Leclaire (1977), não cessa de não se escrever mas se vislumbra na forma de discurso, na forma como a linguagem se organiza textualmente na narrativa. No aspecto narrativo machadiano, um encadeamento fragmentário engendra esse escape, provocando uma suspeita de que há nele palavras por dizer, quando um desvio, uma omissão, uma interrupção se apresentam.

Em Esaú e Jacó, romance objeto de nossa análise aqui, o narrador privilegia sempre esse algo a compreender. $O$ aspecto narrativo deste romance realça a possibilidade de uma leitura psicanalítica que venha a ultrapassar a luta pela fixação de sentido que 
se produz entre o narrador e o leitor (SCHWARZ, 1990), a saber, onde uma ordem desejante venha a ser posta pelo avesso, fazendo atentar para o que está lá como se não estivesse.

O percurso de nossa análise tomará por base, entretanto, a posição das personagens Natividade e o Conselheiro Aires, focalizando um recorte do romance. Por conseguinte, não nos estenderemos a toda tessitura do mesmo em toda a sua amplitude. Acreditamos que esse recorte no aspecto narrativo já nos proporciona as pistas necessárias para um vislumbre do que, em sua construção, aponta para um manejo da linguagem que permite captar as operações discursivas sinalizadoras de uma ordem desejante. Percorramos, portanto, essa sinalização.

É logo no início de Esaú e Jacó que o leitor se depara com o artifício e o mistério. A epígrafe que abre a narrativa, encimando o primeiro capítulo, citação de Dante Alighieri, dá o tom de fatalidade, talvez irônica, que se pode projetar até seu final: "Dico, che quando l'anima mal nata..." Ela traz a injunção de fazer pensar - e agir - no que se segue como um esforço de mudar o destino que, uma vez traçado, vem revelar um imponderável. Ou o esforço para que se cumpra. E, efetivamente, o mesmo leitor, ao final da leitura, poderá vir a testemunhar que o destino se cumpre: por não ser mostrado em detalhes, com antecedência, é inavaliável e, portanto, imutável. Nada se pode fazer para que, ao fim e ao cabo, haja uma reviravolta.

Por outro lado, tudo o que se possa fazer é incorporado ao curso dos acontecimentos, tem parte no destino e conduz a seu termo. A citação de Dante, suspensa por reticências, emoldura uma convenção e a deixa em aberto: "Digo que quando a alma, mal nascida..." ${ }^{3}$ Logo, o destino foi traçado desde quando a alma foi concebida e, ao nascer, estréia seu cumprimento.

A seguir, subindo o morro do Castelo, Natividade e Perpétua se disfarçaram, mas o disfarce as revela, pois "há um donaire que não se perde e não era vulgar naquelas alturas" (EJ, p.1) ${ }^{4}$. Inclusive, "a

Tradução nossa.

Machado de Assis, J. M. Esaú e Jacó. São Paulo: Globo, 1997. As referências a este romance serão tomadas aqui desta edição. 
lentidão do andar, comparada à rapidez das outras pessoas, fazia desconfiar que era a primeira vez que iam ali" (EJ, ibd.). Elas sobem o morro para consultar a cabocla, a adivinha, a respeito do futuro dos filhos de Natividade, os gêmeos Pedro e Paulo.

Uma vez na casa da cabocla, notam a simplicidade: "Não havia nada lá que incutisse pavor ou lembrasse mistério. Um registro da Conceição, colado à parede, podia lembrar o mistério, mas não provocava medo" (EJ, p.2). Afinal chamada, a adivinha entra. Seu aspecto enfatiza o despojamento, mas caracteriza-a como pítia, sacerdotisa. E, logo adiante, o sinal emblemático: "O mistério estava nos olhos" (EJ, p.3). Estes eram "opacos" e "tão compridos, tão agudos que entravam pela gente abaixo, revolviam o coração e tornavam cá fora, prontos para nova entrada e novo revolvimento" (EJ, ibd.).

Eis, notadamente, uma faceta do mistério, pois algo aí a razão não pode explicar nem compreender esse movimento dos olhos que vêem através do coração, revolvem-no verso e anverso, retornando para a mesma operação. Acrescentam-se a isso as qualidades que o nome da cabocla evocam ou revelam - Bárbara $^{5}$-, ampliando o mistério: ela é estranha, a estrangeira que, para os nativos, balbucia, tartamudeia ou fala uma língua desconhecida, ininteligível para os não iniciados. Seu dizer exige uma decifração porque resulta de uma inferência do oculto, cujo alfabeto domina, extraindo dele uma leitura: inclina-se para os retratos dos gêmeos, trazidos pela mãe; aperta as madeixas de seus cabelos, fita-as, cheira-as e as escuta até, finalmente, perguntar se eles haviam brigado antes de nascer, no ventre da mãe (EJ, p.4).

Natividade, que "não tivera uma gestação tranqüila" (EJ, ibd.), já creditando à cabocla a capacidade de prever o futuro, inquieta-se, querendo saber o quanto pode uma briga influenciar o destino dos filhos. E depois de uma atuação, de uma mise-en-scène, a adivinha enuncia: "Cousas futuras" (EJ, p.5) ${ }^{6}$. E assim reintroduz a via do

5 GUÉRIOS, R. S. F. Dicionário de nomes e sobrenomes, p. 68.

6 Cabe referir a Epístola de São Paulo aos hebreus, 11;20: "Pela fé Isaque abençoou Esaú e Jacó no tocante às coisas futuras" (grifo nosso). Bíblia Sagrada. Campinas: Gideões Internacionais, 1995, p.446. Trad. de João Ferreira de Almeida. 
mistério, pois o futuro tem de ser esperado, embora acrescente que os filhos de Natividade alcançarão a glória (EJ, ibd.).

Todavia, mesmo à pítia escapa a explicação de seu vaticínio e se abstrai, encerrando a consulta. Falita, na previsão, algo indizível, que não aproxima do presente uma significação possível e fica em suspense.

A previsão da cabocla do Castelo, da tartamuda, é entrecortada e seus enunciados são vagos, reticentes, interrompidos como a fala dos portadores de gagueira. Estes despertam no interlocutor o esforço de compreensão correlato do esforço de articulação.

A fala do gago é partida, esbarrada em sílabas que ele não pronuncia, em palavras que não diz porque algo lhe atravessa a garganta e o impede. Pronunciado assim, o vaticínio fica esburacado em seu significado e pode evocar todos os sentidos sem que se tenha certeza de qualquer um. Só o "futuro" da previsão enunciada marca o que sucederá. No futuro. Que "cousas", o curso da história, só ele, facultará sua listagem, seu itinerário, seu inventário. Ainda assim, como a arquitetura que o exercício da linguagem edificará, mas preservando um não-dito, um sentido "oculto" a ser isolado dessa edificação com palavras. Há, por conseguinte, algo que se registra na escritura, mas escapa à leitura, como o que foge à escuta numa operação expulsiva.

Ora, o nome da cabocla do Castelo confirma sua fala. O feitio do oráculo é exercitar com palavras o indizível, como se elas estivessem sendo ditas por um outro que está fora, à espreita, perturbador. O nome e a previsão podem ser tomados aqui como um paradigma: é uma tartamuda e estrangeira (a cabocla) que enuncia (a previsão) e, segundo sua palavra, todo um trilhamento deve ser percorrido no que "cousas" torna excessivamente vago o que venha a qualificar como "futuras". É preciso que "cousas" tome uma forma inequívoca a fim de que seja nomeada como fatos, acontecimentos, que ocorrerão depois.

Todavia, a partir do mesmo enunciado - "Cousas futuras" -, apresenta-se uma outra pista: o futuro é modelado pelo desejo indestrutível, à imagem do passado (FREUD, [1900] 1973, p.694). Natividade sonha para os filhos uma vida gloriosa, um porvir de 
grandeza. Ela lhes deu a luz e lhes dará a vida. É essa a sugestão de seu nome: Natividade - nascimento. Mas nascimento se opõe à morte como origem a fim. E, ao saber-se grávida, "que vinha agora uma criança deformá-la por meses, obrigá-la a recolher-se, adoecer dos dentes e o resto" (EJ, p. 15), seu primeiro impulso foi o de "esmagar o gérmen". Só depois, esse impulso é substituído pela sensação melhor da maternidade (EJ, ibd.). Vale assinalar ainda que a notícia da gravidez é dada ao marido, Agostinho, após saírem de uma missa de defuntos (EJ, p. 14).

As oposições entre nascimento e morte, origem e fim, melhor e pior se articulam numa formulação metonímica que opera, efetivamente, um deslocamento de sentido: a glória pela desgraça, a união pela desunião, a amizade pela inimizade, evocado pela pergunta da cabocla: "Eles brigaram antes de nascer?" Aí está uma figuração do desejo que, enfim, é "desejo de ter um desejo insatisfeito" (CATHELINEAU, 1995, p. 43). Natividade não medirá esforços para manter os filhos unidos, mas todo esforço implica torná-los desunidos. Para ela, o futuro se apresenta à imagem do passado em que teve o impulso de esmagar o gérmen. Ou seja, de interromper a gravidez em seu princípio, provocando um abortamento. Embora à sensação de maternidade tenha sucedido o impulso, aquela não o invalida mas o desloca. Assim, a sensação "melhor" de maternidade involucra-o como um disfarce.

O que Roberto Schwarz assinala como volubilidade no procedimento narrativo de Memórias póstumas de Brás Cubas, caracterizando o estilo de seu autor com todas as suas implicações, faz as vezes de deslizador de sentido que identifica a construção metonímica também em Esaú e Jacó: conta a morte antes da vida, a saciedade antes do amor, o fracasso antes da tentativa. Assim, articula convenções que "esterilizam o enredo" (SCHWARZ, 1990, p.69). E essa maneira de narrar, se estende a Esaú e Jacó, embora, em cada um, se especifique um enredo.

Todavia, se o enredo das Memórias, por exemplo, busca seu gancho na História nacional, o de Esaú e Jacó procura ancorar-se nos contos bíblicos, ressignificando-os através de recortes enfiados de esguelha. O seu título logo convida a colocar em perspectiva a rivalidade entre os filhos de Isaque, patrocinada pela mãe Rebeca, e que se reporta às oposições constitutivas da condição humana, às 
concepções dos escolhidos e dos rejeitados por Deus, que carregam desde o nascimento um desígnio escondido, só vislumbrado em seus atos. É por esse viés que se situa um paralelo, no romance, da briga no ventre da mãe, das oposições sucessivas na história dos gêmeos Pedro e Paulo numa luta de puro prestígio?.

Há, ainda, uma sugestão de seus nomes com base em uma inspiração da tia Perpétua (EJ, p. 19) ao rezar o Credo na missa, advertindo nas palavras que enviam aos santos apóstolos São Pedro e São Paulo, ambos mártires e disseminadores da doutrina e da fé cristãs. Mas com antecedentes bem marcados. São Pedro foi muitas vezes admoestado pelo Cristo por causa de sua pouca fé, e censurado por permitir que o demônio falasse por sua boca, caindo em tentação, eufemizando a missão do Filho de Deus na terra, como se ele pudesse mudar o que havia sido traçado pelo Pai. Além disso, São Pedro negou Cristo por três vezes, diante do acosso dos populares que o identificavam como seu discípulo, o que pode ser considerado indicação de covardia ou pusilanimidade. Por outro lado, São Paulo foi um dos maiores perseguidores dos cristãos, antes de se converter no episódio a caminho de Damasco ${ }^{8}$.

Por esse ângulo, vê-se a condução de certas correspondências que suportam uma virtualidade ora alegórica, ora transgressiva, no rastro da construção metonímica, numa ordem de condensações e deslocamentos de sentido. Desse modo, as correspondências são erguidas acima do padrão irrelevante e doméstico dos conflitos entre os gêmeos. Em primeira instância, eles são rivais, mas são crianças; reconciliam-se e tornam a brigar. Sempre as intervenções da mãe revitalizam o círculo da rivalidade, inscrevendo-a como um fato banal que não pode ser excluído do vínculo fraterno e que será resolvido com a maturidade. Afinal, o desafio da conciliação será confirmado ao resolverem suas diferenças no "futuro". Entretanto, apesar dessa possibilidade, a mãe não cessa de preocupar-se. Talvez pela

7 Cf. Gênesis, caps. 25-36.

8 Esses episódios se encontram no Novo Testamento, a saber, em Mateus, 26:69-75; Lucas, 22:52-62; Mateus, 16:21-23; Marcos, 8:31-33 e 14:1527; Atos, 9:1-19. 
indestrutibilidade do passado: a briga antes do nascimento, o impulso de esmagar o gérmen.

As contradições flagrantes ou aparentes que podem ser assinaladas ao longo da narrativa, tais como as citadas acima, ainda confrontam o leitor com uma repetição calculada, levando a pensar que aqui e ali, um monte se revalida tal qual um pano de fundo. Há um modelo onde certos elementos constitutivos aparecem e desaparecem, mas que se configuram sempre, ao fim e ao cabo, como os mesmos, acrescentados ou retirados. Cada acréscimo e cada retirada se articula como o que desvia para retornar ao fundo, ao curso que denuncia uma ordem que não a da realidade que o romance faz "supor". Ou seja: a história que se passa ali é verossímil e seu encadeamento, mesmo aos saltos, é até prosaico. Todavia a expressão e a articulação fazem deduzir um outro sentido dessa verossimilhança e desse prosaísmo.

Ora, o aspecto narrativo inaugurado por Machado de Assis em 1880, com Memórias, vem a repercutir e a se reafirmar em Esaú e Jacó vinte e quatro anos depois. Quanto a esse aspecto narrativo em ambos os romances, na medida em que há um encadeamento nele, há também uma trucagem do nexo realista, "as interrupções, intercalações cifradas, substituições, associações, deformações, condensações e ampliações dão a conhecer uma outra ordem, a do psiquismo, não menos articulada que a outra, bastante à maneira do que Freud indicaria a propósito da elaboração onírica" (SCHWARZ, 1990, p.185).

Machado constrói a narrativa às custas da realidade, porém mediante a utilização imaginária de seus elementos estabelecendo um outro patamar para ela. É a trucagem que coloca "uma perspectiva de deslizamento perpétuo de sentido em que todo o discurso que almeja abordar a realidade é obrigado a manter" (LACAN, 1999, p.83). E junte-se ainda que essa trucagem faz transparecer, no deslizamento de sentido, algo que se repete, que salta para a frente e para trás, colocando-se como um desorganizador ou mesmo pervertedor dessa realidade.

Em Esaú e Jacó, um desorganizador já se introduz em seu primeiro capítulo, quando o narrador inverte a ordem da narrativa e coloca as personagens Natividade e Perpétua indo à casa da advinha a 
fim de saberem o que reserva o futuro para Pedro e Paulo, já com um ano de nascidos. E desse presente empreende uma volta ao passado, recapitulando a concepção e a gravidez, à medida que a situação invoca. Depois, retorna ao presente. Dá-se, desse modo, uma reviravolta no plano narrativo, perturbação paralela à que provoca a previsão da advinha. Além de ancorar o presente, o passado arrasta para trás o futuro, atualizando-se ali como antevisto, mas do qual não se sabe de fato e o qual não se pode, efetivamente, ver.

Esse deslizamento faz com que, ao pé da letra, não se tenha a menor noção onde tudo vai acabar. O que diz a adivinha, na verdade, nada esclarece, só amplia a impossibilidade de saber o que acontecerá e, ainda mais, no futuro e além do presente onde se enuncia a sua previsão. Entretanto, esse presente, no que coloca nele um passado, se põe ali como futuro.

Eis aí uma ordem que se distorce visivelmente, a ordem temporal. Vale um tempo lógico, não o cronológico, pois uma seqüência de acontecimentos, como sua duração, escapam a uma conexão metódica. E esse sentido de tempo, tomado pelo viés psicanalítico, envia a um outro, o do inconsciente, onde uma cronologia é descartada. O tempo do inconsciente é lógico: não há passado, presente ou futuro, mas uma memória permanente, atemporal, cujos conteúdos se dispõem à revelia de uma sucessão ordenada. Isto posto, a história não é o passado, jamais se institui a partir de um começo e sim de avanços e retrocessos pontuados pela repetição. Assim se configura o tempo que regula a encenação do desejo, um percurso sempre abandonado e retomado pela via da insatisfação?.

A narrativa, portanto, é marcada por essa descontinuidade, as conexões obedecem a uma sincronia que acentua a repetição, a uma ordem que independe do tempo. Vale uma ordem desejante, cujo arranjo se subordina ao princípio de satisfação do desejo, de sua expressão disfarçada.. E uma regularidade que esse princípio permite é aquela onde o desejo é pontuado pelos elementos que referem sua encenação. Ora, se o futuro é modelado pelo desejo indestrutível, à

9 Lacan, I. "Le temps logique et l'assertion de certitude antecipée. Un nouveau sofisme." In: Ecrits, p. 197-201. . 
imagem do passado, o presente sempre configura uma cena na sequiência completa de sua realização imaginária. Ao fim e ao cabo, ela tem seu fecho, seu termo, que se coaduna com o que o passado determinou, projetando-se no futuro como um correlato do cumprimento do destino.

A afirmação de Mikhail Bakhtin (1993, p. 425) ${ }^{10}$ de que um dos motivos intrínsecos do romance é exatamente o da inadequação de um personagem a seu destino e à sua situação torna-se questionável. $\mathrm{O}$ que se tem demonstrado por Machado de Assis em Esaú e Jacó é que esse motivo - da inadequação - converie-se numa conformidade, incorporado à narrativa, somado a outros, dispostos em seu percurso. São indissociáveis as personagens, seus destinos e suas situações. Deparando-se com o mistério, logo no início desse romance, o leitor se depara também com esse vínculo. Como já colocamos antes, o curso dos acontecimentos tem incorporado tudo o que se possa fazer e isto tem parte no destino, conduzindo a seu termo.

Certamente, o que o vínculo sugere não é a premeditação caprichosa do narrador mas um aspecto construído em torno do objeto da narração. É a forma de arquitetar a encenação do desejo, forma de dizer que o homem não é, de fato, superior ao seu destino nem inferior à sua humanidade. Embutida aí está a proposição de que a cada um cabe aquilo que sua obra confere, expressão bem voltaireana, de um vago teísmo, afirmadora da liberdade e do arbítrio. A despeito de qualquer argumentação contrária, Deus existe bem como sua ação providencial no universo $^{11}$. E este axioma, refratado pelo disfarce, compõe uma das facetas do aspecto narrativo, encarnado, em Esaú e Jacó, na personagem José da Costa Marcondes Aires.

Introduzido na trama, o conselheiro Aires paira como uma águia $^{12}$, desde sua apresentação $(E J$, p.27) até o fim do romance. Ou

10 A afirmação de M Bakhtin: "Um dos principais temas interiores do romance é justamente o tema de inadequação de um personagem a seu destino e a sua situação. O homem ou ć superior ao seu destino ou é inferior a sua humanidade". Questões de hitcratura e de estética: a teoria do romance, p. 425.

11 Arouet, F.M. dito Voltaire. Dicionário Filosófico, p. 156-159.

12 Águia é o significado do sobrenome Aires. Guérios, R.F.M. op. cit. p. 50 
transita. Um cenário adequado se monta para seu surgimento, com os elementos necessários.

Descontente, ou obcecado, com a insinuação da adivinha - a cabocla do Castelo - de que os gêmeos brigaram no ventre materno, Agostinho, seu pai, vai visitar o amigo Plácido, mestre versado na doutrina espírita e lá encontra Aires, o qual toma parte na discussão que busca explicar a briga cujos indícios possíveis se verificam na gravidez da mãe. E a apresentação do conselheiro o compõe como personagem: "Diplomata de carreira, trazia o calo do ofício, o sorriso aprovador, a fala brande e cautelosa, o ar da ocasião, tudo tão bem distribuído que dava gosto ouvi-lo e vê-lo" (EJ, p.27-28). Sua descrição é aditada a seguir de um "tempo houve em que ele também gostou de Natividade" (EJ, p.28). Adiante, citada como "coincidência! interessante", há a intenção de Agostinho de casá-lo com a cunhada, Perpétua, viúva recente na ocasião, ao que Natividade se opôs: "O desgosto de cedê-lo à outra, ou de tê-los felizes ao pé de si, não podia ser, posto que o coração seja o abismo dos abismos. Suponhamos que era o fim de o punir por havê-la amado" (EJ, ibd.).

Mas aí está uma suposição de fato, porque nunca se soube o motivo verdadeiro da oposição de Natividade ao casamento. E logo vem um eufemismo: "Pode ser: em todo o caso, o maior obstáculo (ao casamento) viria a ser ele mesmo (Aires)" (EJ, ibd.). Revela-se dessa forma uma idiossincrasia do conselheiro, o "tédio à controvérsia" (EJ, p.29), porque se dispunha a evitar tudo. Num encontro, referido como anterior ao que se deu em casa de Plácido, em visita aos pais dos gêmeos, quando Perpétua solicitou sua opinião acerca da cabocla do Castelo, ele "opinou com pausa, delicadeza, circunlóquios, limpando o monóculo no lenço de seda, pingando as palavras graves e obscuras, fitando os olhós no ar, como quem busca uma lembrança, e achava a lembrança e arredondava com ela o parecer." (EJ, ibd.).

$\mathrm{Na}$ ocasião, a curiosidade da solicitante de saber sua opinião sobre a adivinha o faz intuir, conclusivamentě, que ela, ou a irmã quer consultar a adivinha, levando a intuição ao seu Memorial ${ }^{13}$ : "Noite em casa da família Santos [...]. Falou-se da cabocla do Castelo. Desconfío

13 Referência ao Memorial de Aires, romance posterior do autor. 
que Natividade ou a irmã quer consultá-la: não será a meu respeito" (EJ, ibd.).

Introduzindo-se Aires na narrativa, com seu tédio à controvérsia e com sua intuição, se introduz nela, como também na trama, o risco das convenções, ou seja, do que não é natural mas acordado, uma vez que, de início, não há nenhuma razão para que o escrito ou o dito corresponda a uma significação determinada. $\mathrm{O}$ narrador comunica o seguinte sobre o parecer acima referido: "Um dos ouvintes aceitou-o logo, outro divergiu um pouco e acabou de acordo, assim um terceiro, e um quarto e a sala toda" (EJ, ibd.). Todavia, o leitor não tem conhecimento do parecer, levando a concluir que a carapuça, que investe a personagem, investe também a posição ou função na trama. Aires, "que resistia às verdades eternas" (EJ, p.27) e que "não era fácil de convencer" (EJ, p.31), faz convencionar.

Outrossim, questionado sobre a briga dos gêmeos antes de nascerem, ele dá uma resposta "temperando o sentido afirmativo com uma entonação dubidativa", originando uma polêmica: "Antes de nascer, crianças não brigam" (EJ, ibd.). E isso o faz usar, para afastá-la - a polêmica -, o exemplo bíblico dos filhos de Isaque e Rebeca, cujo conflito se conhece a causa. Quanto aos outros casos, a "Providência esconde" a causa da "notícia humana" (EJ, p.23). Por fim, citando Empédocles - "A guerra é a mãe de todas as coisas" -, deriva para o amor "como um duelo, não de morte, mas de vida" (EJ, ibd.), finalizando com um sorriso leve, falando baixo, despedindo-se da polêmica. Sua argumentação e conclusão são consideradas plausíveis.

O tédio à controvérsia, que introduz o risco das convenções, vem a revelar seus derivativos como operações discursivas: a ironia, já excessivamente conhecida no texto machadiano, e o eufemismo, ambos regulados pela antífrase. Através da ironia, se diz, e se escreve, o contrário do que as palavras significam e o eufemismo é toda maneira suavizada ou atenuada de se exprimir certos fatos ou idéias cuja crueza pode ferir. Entretanto, no que pese a regulação antifrásica, tanto a ironia como o eufemismo podem exprimir o oposto do que se escreve $^{14}$.

14 Dubois, Jean et al. Dicionário de lingüística, p. 56 e 225. Michaelis. Moderno dicionário da língua portuguesa, p. 1180. 
Ao suavizar o motivo possível da briga dos gêmeos no ventre da mãe, Aires faz deslizar os sentidos da citação de Empédocles, tomando a "paz" e o "amor" como substitutos contrários à "guerra" e ao "ódio", este e aquela não referidos no deslize. Desse modo, o amor, embora um duelo de vida é também, efetivamente uma guerra, um embate. Coloca-se aí uma equivalência aparente de significado só forjada por convenção que faz deslocar a guerra para o amor desde a citação do filósofo, embutindo o ódio que não se enuncia e, por conseguinte, na frase de Aires, surtindo um efeito suspensivo. Ora, luta-se por amor como se luta por prestígio. Em ambas as lutas, chegase a um fim como solução dos impasses. Mas a solução dos impasses na luta por amor é a paz e, na luta pelo prestígio, a solução dos impasses é a morte.

Em primeira instância, as operações discursivas se equiparam a recursos estilísticos, ou a um instrumental retórico - a ironia, o eufemismo. Todavia, ultrapassam essa função. Modulando a narração e temperando a trama a cada momento em que se efetivam, não somente fazem cessar qualquer controvérsia - como é o caso dos pareceres de Aires -, fazem-na também permanecer em suspense para ser tomada logo mais. Dessa maneira, algo é recolhido para que não continue ali ou a fim de que, não visualizado nem identificado, fique da forma que está sem ser anulado. Ou seja: no caso da explicação da briga, ela é sempre aventada e até enunciada enquanto explicação, mas não é explicada e assim permanece para ser retomada, de outra forma, adiante, em seus desdobramentos. Quanto mais se processa a explicação, mais se faz com que o motivo da briga seja inexplicado. Isso imprime à procura um duplo sentido: existe a explicação, porém ela é vedada ao conhecimento.

Se a mãe, Natividade, teve como primeiro impulso, ao saberse grávida, o de esmagar o gérmen, isso equivale à intenção de abortar e a sensação posterior de maternidade não anula mas o suspende. Afinal, a citação de Empédocles se faz valer, enviesada. Enquanto nela a guerra é a origem de todas as coisas, aquele impulso de morte é a razão da briga dos gêmeos no ventre da mãe. É por essa via que a controvérsia é retomada, a controvérsia que enuncia o desejo da mãe, o qual vem a se encenar a posteriori, com a permanente rivalidade e briga entre os gêmeos, pontuadas por tréguas momentâneas, trazendo a oposta possibilidade de conciliação e de paz. E vale salientar ainda 
que desse impulso somente a mãe sabe, registrado como reminiscência que de fato se anularia se fosse lembrado.

O tormento de ver os filhos rivais não cessa para Natividade. Aires será a testemunha esquiva ou participante dele: será convidado a ocupar a posição de cúmplice ou aconselhador. E num encontro casual, ela lhe confessa suas preocupações, casualidade que parece vir a propósito. O encontro se dá no bonde (EJ, p.74). Natividade faz a Aires uma confidência. Conta a rivalidade entre os filhos, falando especialmente de Paulo. A consulta à cabocla vem à memória e o receio de que o conselheiro a tenha adivinhado, pela alusão que ele mesmo faz, lembrando o dia em que Perpétua lhe pediu a opinião sobre a pítia. Mais uma vez a fala da cabocla ecoa e, nessa altura, trata-se do que está ocorrendo no futuro em relação ao passado em que a mesma se deu: Eles teriam brigado antes de nascer.

O que Natividade quer é reverter isso, mudar ou anular. Aires argumenta com a questão: "O que é definitivo nesse mundo?" (EJ, p.75). Todavia ela replica:

- Sabe muito bem que meus dous gêmeos não combinam em nada, ou só um pouco, por mais esforços que eu tenha feito para os irazer certa harmonia. Agostinho não me ajuda; tem outros cuidados. Eu mesma não me sinto com forças, e então pensei que um amigo, um homem moderado, um homem de sociedade, hábil, fino, cauteloso, inteligente, instruído... (grifo nosso) (EJ, p.77).

E nessa descrição, Aires se reconhece - vale-se, neste ponto, de seu tédio à controvérsia - e indaga o que pode fazer. Ela protesta "que pode corrigi-los por boas maneira, fazê-los unidos ainda que discordem, e que discordem pouco ou nada" (EJ, ibd.). Ao que o conselheiro sentencia, após argumentar: "Já lhe disse que toda a minha ação é inútil". Apesar disso, Natividade insiste e ele acaba prometendo tentar o que ela pede, em silêncio (EJ, p.78).

Valeria salientar aqui, de passagem, essa posição ou a função em que a mãe dos gêmeos coloca Aires, em detrimento do pai, Agostinho, que em nada ajuda e tem outros cuidados. O conselheiro é ascendido ao lugar de pai simbólico, cuja investidura, idealizada, opera limitando e ordenando o desejo. Trata-se de uma atribuição que 
se opõe à do pai real, cuja carência arremete a impasses, dificuldades, inibições. Este é o pai de fato, Agostinho, de que muito se espera, mas não representa o valor simbólico de sua função, só operando o acesso ao desejo, em particular, mas não ao seu limite e ordenação (CHEMANA, 1995, p.158-159). Pode-se referir aqui, de outro modo, que o vaticínio da cabocla do Castelo fundiu no pai dos gêmeos uma opção na realidade familiar que se fundamenta na glória e na grandeza a eles destinada no futuro. A obsessão inicial por saber a causa da briga dos filhos no ventre da mãe se desloca para uma espécie de certeza posterior desse destino, eximindo-o de intervir no presente, como se o fim justificasse os meios. Daí poder ter outros cuidados, talvez pelo que ele julga ser de sua responsabilidade.

Ora, o lugar que Natividade faz Agostinho ocupar faz também com que a sentença de Aires se ajuste como uma luva aos atributos de sua investidura. Pois vem a querer

cumprir deveras o ofício que aceitara de Natividade. Quem sabe se a idéia de pai espiritual dos gêmeos, pai de desejo somente, pai que não foi, que teria sido, não lhe daria uma afeição particular e um dever mais alto que o de simples amigo? (grifo nosso) (EJ, p.87).

A sentença de Aires traz aqui, novamente, uma reafirmação da indestrutibilidade do passado. Infortunadamente, não se trata do passado da fala da adivinha do Castelo, da insinuação chocante da contenda dos gêmeos antes de nascer, e sim do desejo de morte que desliza daí para fora e a lembrança da fala, que inquieta, é tomada, pela operação metonímica, como se o fosse. Aí está, no dito, uma pista para o indizível, o intolerável, que não cabe no "sentimento de maternidade". Confessando a inutilidade de tudo o que vier a fazer, mas aceitando a solicitação da mãe, prometendo agir em silêncio, Aires, em primeira instância, coloca um ponto a partir do qual o nãodito pode ser designado e, em segunda instância, acata a investidura de pai simbólico.

Nesse lance, como em tantos outros, o narrador se regala com sua maestria em fazer deslizar o sentido da abordagem da realidade do desejo. Considere-se, por isso, que essa realidade, para ser abordada, exige o esforço de enunciá-la no discurso, esforço este que jamais consegue nada além de mostrar o que a introdução do discurso 
acrescenta de desorganizador e perverso a ela (LACAN, 1999, p.83). Pois bem, o desejo pode ser limitado e ordenado, certamente transformado, porém nunca destruído, mudado ou anulado.

Essa realidade do que se trata? Primeiramente, há uma repetição, uma insistência, sempre aludida na narrativa, do empreendimento de Natividade visando manter os gêmeos unidos, tendo a contrapartida da desunião e da expectativa de vê-los se destruírem. O empreendimento, então, se polariza e tem existência frente à contrapartida como se procedesse dela. Em segundo lugar, a mesma repetição realiza a possibilidade iminente, a cada passo, dos gêmeos se destruírem como se, apesar de tudo, alguma coisa pudesse ser feita para evitá-lo. Retomando mais uma vez a sentença de Aires e remontando-a, dar-se-ia que toda a ação para evitá-la seria inútil. O que não é dito é que, ao fim e ao cabo, o desejo se realizará, o desejo se encenará, como se encena um sonho, diferentemente do que a expectativa projeta na subjetividade.

\section{Referências}

AROUET, F. M. (dito Voltaire). Dicionário filosófico. São Paulo: Abril Cultural, 1973.

BAKHTIN, M. Questões de literatura e estética: a teoria do romance. São Paulo: Unesp/Hucitec, 1993.

BÍBLIA SAGRADA. Campinas: Gideões Internacionais, 1995, p. 466. Trad. João Ferreira de Almeida.

BLOOM, H. O cânone ocidental. Rio de Janeiro: Objetiva, 1995.

CATHELINEAU, P. C. Desejo. In: Dicionário de psicanálise. Org.CHEMAMA, R. Porto Alegre: Artes Médicas, 1995, pp. 42-46.

CHEMAMA, R. Pai real, pai imaginário, pai simbólico. In: Dicionário de psicanálise. Org.CHEMAMA, R. Porto Alegre: Artes Médicas, 1995, pp. 158-159.

DUBOIS, J. et al. Dicionário de lingüística. São Paulo: Cultrix, 1995. 
FREUD, S. La Interpretacion de los Sueños. In: Obras completas. Madrid: Biblioteca Nueva, 1973, Vol. I, pp. 343-720.

GUÉRIOS, R.F.M. Dicionário etimológico de nomes e sobrenomes. São Paulo: Ave Maria, 1981.

LACAN, J. Écrits. Paris: Editions du Seouil, 1966.

LACAN, J. O Seminário. Livro 5: As formações do inconsciente. Rio de Janeiro: Jorge Zahar, 1999.

LECLAIRE, S. Desmascarar o real. Lisboa: Assírio e Alvim, 1977.

MACHADO DE ASSIS, J.M. Esaú e Jacó. São Paulo: Globo, 1997.

MACHADO DE ASSIS, J.M. Memorial de Aires. São Paulo: Globo, 1997.

MACHADO DE ASSIS, J.M. Memórias póstumas de Brás Cubas, São Paulo: Ática, 2000.

MICHAELIS. Moderno dicionário da língua portuguesa. São Paulo: Melhoramentos, 1998.

SCHÜLER, D. Teoria do romance. São Paulo: Ática, 1989.

SCHWARZ, R. Um mesire na periferia do capitalismo / Machado de Assis/. São Paulo: Duas Cidades, 1990. 